\section{NưN Kastamonu Eğitim Dergisi Kastamonu Education Journal}

Eylül 2019 Cilt:27 Sayı:5

kefdergi.kastamonu.edu.tr
Başvuru Tarihi/Received: 02.07.2018

Kabul Tarihi/Accepted: 22.01.2019

DOI: $10.24106 /$ kefdergi.3198

\title{
Lise Öğrencilerinde İnternet Bağımılığının Çeşitli Değişkenler Açısından İncelenmesi
}

\section{An Analysis of Internet Addiction Among High School Students with Respect to Several Variables}

\section{Öz}

\author{
Sinem FARIZ1 ${ }^{1}$, Safiye SARICI BULUT²
}

Bu araştırmanın amacı lise öğrencilerinin internet bağımlılığı düzeyleri ile cinsiyet, aile gelir düzeyi, anne ve baba öğrenim durumu, algılanan sosyal destek düzeyi ve akademik başarı arasındaki ilişkiyi incelemektir. Araştrma, 2015-2016 eğitim-öğretim yılında Ankara'nın Sincan ilçesinde dört faklı lisede (Anadolu Lisesi,Endüstri Meslek Lisesi,Ticaret Meslek Lisesi ve Kız Meslek Lisesi) öğrenim görmekte olan 358 (175 kız, 183 erkek) öğrenciyle gerçekleştirilmiştir. Araştırmaya katılan öğrenciler dört farklı tür okuldaki 9, 10 ve 11.sınıf öğrencilerinden elverişli örnekleme yöntemiyle seçilmişlerdir. Bu çalışmada, veri toplama araçları olarak araştırmacı tarafindan geliştirilen Katılımcı Bilgi Formu, Öğrencilerin internet bağımlılık düzeylerini ölçmek üzere Young (1998) tarafindan geliştirilen “internet Bağımlııı̆ı Ölçeği" (iBÖ), sosyal destek algılarını değerlendirmek üzere Yıldırım (2004) tarafindan revize edilen Algılanan Sosyal Destek Ölçeği (ASDÖ-R) kullanılmıştır. Araştırma verileri Ki kare ve t-testi kullanılarak analiz edilmiştir. Araştırma bulgularına göre, lise öğrencilerinin internet bağımlılı̆ı puanlarının aile gelir düzeyi değişkenine göre ve ASDÖ-R'nin "Öğretmen Desteği" ve "Aile Desteği" alt ölçek puan ortalamalarının internet bağımlılık düzeyi değişkenine göre anlamlı olarak farklılaştığı belirlenmiştir.

Anahtar Kelimeler: akademik başarı, internet bağımlılı̆̆ı, sosyal destek

\section{Abstract}

The purpose of the study is to investigate the relationship between the level of high school students' internet addiction and gender, family income, parents' education status, perceived level of social support and academic achievement. The study was conducted with a total of 358 students, consisting of 183 males (\%51.1) and 175 females (\%48.9), who continue their education in four different types of high school (Anatolian High School, Industrial Vocational High School, Trade Vocational High School, Girls' Vocational High School) in Sincan, Ankara in 2014-2015 academic year. These students were selected through convenience sampling method from students studying in the 9th, 10th, and 11th grades at four different school types. In this study, Participant Information Form developed by the researcher, "Internet Addiction Scale (IAS)" which was developed by Young (1998) to measure the internet addiction level of the students and Perceived Social Support Scale (PSSS) which was revised (PSSS-R) by Yildirim (2004) to evaluate social support perceptions, are used as data collection tools. The data were analyzed by using Chi square and t-test. According to findings of the study, it was determined that high school students' internet addiction scores significantly differ in terms of family income variable and mean scores of "Teacher Support" and "Family Support" subscales of PSSS-R significantly differ in terms of level of internet addiction variable.

Keywords: academic achievement, internet addiction, social support

1 Sinem FARiZ, Sakarya Üniversitesi, Eğitimde Psikolojik Hizmetler Bilim Dalı Doktora Öğrencisi, Sakarya, Türkiye; http://orcid.org/0000-0002-4728-5926 2 Safiye SARICI BULUT, Gazi Üniversitesi Eğitim Fakültesi, Rehberlik ve Psikolojik Danışmanlık Anabilim Dalı, Ankara, Türkiye; https://orcid.org/0000-0001-6557-3668 Atff / Citation: Fariz, S. \& Bulut, S. S. (2019). Lise öğrencilerinde internet bağımlılığııı çeşitli değişkenler açısından incelenmesi .Kastamonu Education Journal, 27(5), 1977-1990. doi:10.24106/kefdergi.3198 


\section{Extended Abstract}

Introduction: It is seen that the use of internet has become increasingly widespread in our country in parallel with the worldwide use. Internet is used more and more common with many things that make our life easier; however, this uncontrolled use causes people to face many problems in areas such as school, family, and health (Gönül, 2002; Morahan-Martin and Schumacher, 2000). Since the adolescence is a period during which important decisions regarding the future are taken, identity is formed, and anxiety about success increases, it becomes especially significant to evaluate the adolescents' habits of internet use and status of their addiction. Although internet addiction is a type of addiction that can be seen at any age, in the adolescence period there are much more demanding and risk factors because in this period rapid changes and emotions are experienced. In this direction, the purpose of the study is to investigate the relationship between the level of high school students' internet addiction and gender, family income, parents' education status, perceived level of social support and academic achievement.The present research aims to provide more conclusive answers to the following research questions:

1. Are the high school students' levels of internet addiction significantly different in terms of gender?

2. Are the high school students' levels of internet addiction significantly different in terms of their family income?

3. Are the high school students' levels of internet addiction significantly different in terms of their mothers' education status?

4. Are the high school students' levels of internet addiction significantly different in terms of their fathers' education status?

5. Are the high school students' levels of internet addiction significantly different in terms of perceived social support (family, teacher, friend)?

6. Are the high school students' levels of internet addiction significantly different in terms of their academic achievement?

Method: The research approach that aims to describe the past or present as it exists is the survey model. Relational research in the survey model aims to determine the presence or degree of variation between two or more variables (Karasar, 2014). Examining the relationship between the level of high school students' internet addiction and variables of gender, parents' education status, family income, academic achievement, perceived level of social support in this study necessitate using relational survey model.

Results and Discussion: The study was conducted with a total of 358 students, consisting of 183 males (\%51.1) and 175 females (\%48.9), who continue their education in four different types of high school (Anatolian High School, Industrial Vocational High School, Trade Vocational High School, Girls' Vocational High School) in Sincan, Ankara in 20142015 academic year. These students were selected through convenience sampling method from students studying in the 9th, 10th, and 11th grades at four different school types. In the study, Participant Information Form which was developed by the researcher, "Internet Addiction Scale" (IAS) which was developed by Young (1998) and adapted to Turkish by Bayraktar (2001) in order to measure the level of students' internet addiction, the revised form of Perceived Social Support Scale (PSSS-R) by Yıldırım (2004), which had been developed by Yıldırım (1997), in order to evaluate perceptions of social support were used as data collection tools.

The data were analyzed by using Chi square and t-test. According to findings of the study, it was determined that high school students' internet addiction scores significantly differ in terms of family income variable and students who did not display the symptom of internet addiction had a significantly higher mean perceived social support score than students who displayed the symptom of internet addiction. That the level of family income was below or above the average was determined to make a significant difference for the students whether to show the symptom of internet addiction or not. It was seen that the students who come from families having a lower or higher level of income experience the symptom of internet addiction much more than students in medium level of income. Furthermore, the perceived social support from family and teacher subscale scores of the students who did not display the symptom of internet addiction were determined to be significantly higher than students who displayed the symptom of internet addiction. In terms of the subscale scores of friend in the perceived social support scale, no significant difference was found between the students who displayed and who did not display the symptom of internet addiction. 


\section{Giriş}

Dünya üzerindeki ağların ortak bir düzenleme içerisinde iletişim kurmasını ve kaynak paylaşımını sağlayan ağlar arası bir ağ olarak tanımlanan internet, ingilizce "uluslararası" ve "ağ" sözcüklerinin birleşiminden türemiştir (Tsai, Lin ve Tsai, 2001; Yalçın,2003). Ögel (2014) internetin insanlığın gelişim sürecinin geldiği önemli bir nokta olduğunu belirtmektedir. Bu buluş; ilkçağ insanlarının ateşi bulmasından, tekerleği icat etmesinden ya da aletler üreterek hayat kolaylaştırmasından farklı değildir. İnternet tüm bu gelişimlerin karşıtı değil aksine devamıdır ve medeniyetin bugün geldiği noktada teknolojik gelişimle beraber önemli bir yere sahiptir. İnternet bilgiye erişimi kolaylaştrır, iletişimdeki zaman ve maliyeti minimuma indirger, anonim iletişim ortamı sunarak bireylerin kimliklerini özgürce ifade edebilmelerini sağlar, zahmetsizce alışveriş yapma imkanı sunar. İnternetin sağladığı bütün bu fırsatlar ile birlikte günümüzde internete erişimin kolaylaşması ve maliyetin uygun hale gelmesi, internet kullanımının giderek daha yaygın hale gelmesini sağlamaktadır. (Aydoğdu, 2003; Kang, Kim, ve Park, 2014; Yadav, Banwari, Parmar, ve Maniar, 2013).

Internet World Stats (IWS, 2015) verileri Avrupa'da internet kullanıc sayısının beş yüz milyonu aşthğını belirtmektedir. Aynı yıl Türkiye'de kullanıcı sayısı 46 milyonu aşmıştır. 2015 yılında ülkemiz; Rusya, Almanya, İngiltere ve Fransa'dan sonra Avrupa'da internetin en fazla kullanıldığı beşinci ülke olmuştur. IWS 2017 Aralık ayı verilerine göre de Avrupa'da internet kullanım oranlarında sıralamanın değişmediği görülmektedir. En son yayınlanan IWS 2019 Haziran ayı verileri ise Avrupa'da internet kullanım oranlarında Türkiye'nin, Rusya ve Almanya'dan sonra üçüncü sırada yer aldığını ve Türkiye'den sonra sırasıyla İngiltere ve Fransa'nın Avrupa'da en fazla internet kullanıcısına sahip ülkeler olduğunu ortaya koymaktadır. Dünya genelindeki internet kullanıcı sayısına bakıldığında; 2015 Haziran ayı itibariyle kullanıcı sayısı 3 milyarı geçmiş, 2016 yııında da rakam artş göstermiş, 2017 yılına gelindiğinde kullanııı sayısı Aralık ayında 4 milyarı aşmış, 2019 Haziran ayı itibariyle de internet kullanıcı sayısı 4,4 milyara ulaşmıştır ve bu sayı dünya nüfusunun \%57.3'ü olarak ifade edilmektedir (Internet World Stats [IWS], 2015, 2016, 2017,2019). İnternet kullanımı dünya genelindeki seyrine paralel olarak ülkemizde de giderek yaygınlaşmaktadır. Türkiye İstatistik Kurumu (TÜiK, 2018) hanehalkı bilişim teknolojileri kullanım araştırması verilerine göre Türkiye genelinde hanelerin \%83,8'inde internete erişim imkanı bulunmaktadır. Aynı araştırmanın 2017 yılındaki sonuçları ülkemiz genelinde hanelerin \%80,7'sinin internete erişimi olduğunu, 2016 yılındaki sonuçları hanelerin \%76,3'ünün internete erişim imkanına sahip olduğunu söylerken 2015 yılı araştırma sonuçları oranın \%69,5 olduğunu göstermektedir. İnternet yaşamımıza sağladığı kolaylıklar ile giderek daha yaygın kullanılmaktadır ancak kontrolsüz kullanımla birlikte bu durum bireylerin aile, okul ve sağlık gibi birçok alanda daha çok sorun yaşamalarına yol açmaktadır (Gönül, 2002; Morahan-Martin ve Schumacher, 2000).

İnternet bağımlılığı her yaşta görülebilen bir bağımlılık türüdür ancak ergenlik döneminde hızlı ve büyük değişimlerin gerçekleşmesi ile duygulanımda görülen iniş ve çıkışlar ergenliği risk faktörlerinin fazla olduğu bir dönem haline getirmektedir. Ergenlerin bu zorlu dönemi başarıyla atlatmaları ebeveynleri ve akranlarıyla sağlıklı ilişkiler kurabilmeleri ile yakından ilişkilidir (Bayraktar, 2007; Gürcan, 2010; Kozaklı, 2006). Sanders, Field, Diego, ve Kaplan'ın (2000) yaptikları çalışmada internet kullanımı fazla olan ergenlerin sosyal bağları zayıf olarak bulunmuştur. Bunun tersi olarak internet kullanımı az olan ergenlerin arkadaşları ve anneleri ile ilişkilerinin daha iyi olduğu görülmüştür. Mitchell, Lebow, Uribe, Grathouse, ve Shoger (2011) bireylerin internet kullanım amaçlarının sosyal destek düzeyine göre değiştiğini ve algılanan sosyal destek düzeyi düşük olanların daha yoğun olarak zarar verme ve oyun oynama amacıyla interneti kullandıklarını belirlemişlerdir. Aynı araştırmada mutsuz bireylerin de interneti daha çok zarar verme amacıyla kullandıkları belirlenmiştir. Pawlak (2002)'ın araştırmasında da lise öğrencilerinin sosyal destek ve yalnızlık değişkenleri ile internet bağımlılıkları arasında ilişki olduğu belirlenmiştir.

Ergenlik döneminde önemli kararların alınmasının gerekliliği ve böylelikle geleceğin şekillendirilmesi ve kimlik kazanımının gerçekleşmesi gereken bir dönem olması nedenleriyle ergenlerin başarı konusundaki kaygılarının yüksek olduğu görülmektedir (Mossbarger, 2008). Esen (2010) ergenlerin internet bağımlılığının olumsuz sonuçlarını sosyal, ailesel, iliş̧isel, akademik ve sağıkla ilgili alanlar olmak üzere birçok boyutta yaşadıklarını belirtmektedir. Duman (2008) tarafindan lise öğrencileri ile gerçekleştirilen çalışmada öğrencilerin \%95'i internet kullanımı dolayısıyla daha az ders çalıştıklarını belirtirken öğrencilerin \%55'i de internette geçirdikleri zamanın derslerde geri kalmalarına neden olduğunu ifade etmişlerdir. Aynı araştırmada öğrencilerin \%90'ı ailelerinin maddi olanaklarının ve evdeki imkanlarının ders çaIışmaları için uygun olduğunu belirtmişlerdir. Suhaill ve Bargess (2006)'in çalışmasında da öğrencilerin \%31'i akademik başarılarında internet kullanımlarına bağıı olarak düşüş olduğunu belirtmişlerdir.

İnternet bağımlılığını açıklayan pek çok model bulunmaktadır. Caplan (2002) geliştirdiği modelde bireylerin sanal ortamda kendilerini daha rahat hissetmeleri nedeniyle internetin aşırı kullanımı ve devamında problemli internet kullanımı ortaya çıktı̆ını ifade etmektedir. Suler (1999) bireylerin; cinsel, kişiler arası temas, öğrenme ve saygınlık, ait olma ve kendini gerçekleştirme intiyaçları doğrultusunda internet kullanımının şekillendiğini belirtmektedir. Grohol 
(2012)'un patolojik internet kullanımı modeli ise bağımlılığın temelinde sosyalleşme olduğunu vurgulamaktadır. Özellikle gerçek yaşamlarında sosyalleşmekte güçlük gösteren bireylerin internet ortamında sosyal etkileşim ihtiyacında olduğunu ifade etmektedir. Bu modellerin sosyal etkileşim, sosyal kaygı ve bireysel ihtiyaçlara yapttkları vurgunun yanı sıra ergenlik dönemi gelişimsel özellikleri düşünüldüğünde ve Ögel (2014) ile Kuran (2018)'ın da ifade ettiği gibi 2000 senesi ve sonrasında doğan "Z nesli" ya da "yeni sessiz nesil" için internetin tutum ve davranışların gelişiminde önemli bir kaynak durumunda olması nedenleriyle bu araştırmada özellikle ergenler ile çalışılmıştır. Ayrıca internet bağımlılığı modellerinde sosyal intiyaçlar ve özellikle sosyal etkileşimin öneminin vurgulanması dolayısıyla öğrencilerin sosyal destek algıları incelenmiştir. İnternet bağımlıığına ilişkin çalışmalarda cinsiyet, gelir düzeyi ve akademik başarının sıklıkla incelenen değişkenler olmakla birlikte araştırmacıların bulgularında farklılıklar olduğu görülmektedir. Bu doğrultuda alanyazına katkı sağlaması bakımından bu araştırmanın amacı lise öğrencilerinde internet bağımlılı̆ını çeşitli değişkenlere (cinsiyet, aile gelir düzeyi, anne öğrenim durumu, baba öğrenim durumu, akademik başarı ve algılanan sosyal destek) göre incelemek olarak belirlenmiştir. Ülkemizde ve dünyada internet erişim imkanlarının ve kullanımının giderek artmakta olduğu göz önüne alındığında sağlıklı internet kullanımı daha önemli hale gelmektedir. Özellikle interneti en çok kullanan grup olmaları ve ülkemizin genç nüfus oranı göz önüne alındığında ergenlerin bilinçli internet kullanımı konusunda desteklenmeye intiyaçları bulunmaktadır. İnternet bağımlılığının sebep ve sonuçlarıyla daha iyi anlaşılması ve ergenlerin ihtiyaçlarını belirleyerek önleyici ve müdahale edici çalışmaların planlanması adına araştırma verilerinin alana katkı sağlayacağı düşünülmektedir.

\section{Araştırmanın Amacı}

Bu araştırmanın amacı lise öğrencilerinde internet bağımlıı̆ını çeşitli değişkenler (cinsiyet, aile gelir düzeyi, anne ve baba eğitim düzeyi, algılanan sosyal destek ve akademik başarı) açısından incelemektir. Bu doğrultuda araştırmada aşağıdaki sorulara yanıt aranmıştır.

1. Lise öğrencilerinin internet bağımlılık düzeyleri cinsiyete göre anlamlı olarak farklı mıdır?

2. Lise öğrencilerinin internet bağımlıık düzeyleri ailenin gelir düzeyine göre anlamlı olarak farklı mıdır?

3. Lise öğrencilerinin internet bağımlılık düzeyleri annelerinin öğrenim durumuna göre anlamlı olarak farklı mıdır?

4. Lise öğrencilerinin internet bağımlıık düzeyleri babalarının öğrenim durumuna göre anlamlı olarak farklı mıdır?

5. Lise öğrencilerinin internet bağımlılık düzeyleri algılanan sosyal destek (aile, öğretmen, arkadaş) durumuna göre anlamlı olarak farklı mıdır?

6. Lise öğrencilerinin internet bağımlılık düzeyleri akademik başarıya göre anlamlı olarak farklı mıdır?

\section{Yöntem}

\section{Araştırma Modeli}

Tarama modeli, halen var olan ya da geçmişte var olmuş bir durumu olduğu haliyle betimlemeyi amaçlayan bir araştırma yaklaşımıdır. Tarama modelinde ilişkisel araştırmalar ise, iki ya da daha çok sayıdaki değişken arasında birlikte değişim varlığını veya derecesini belirlemeyi amaçlamaktadır (Karasar, 2014). Bu araştırmanın değişkenleri ve amaçları dikkate alınarak ilişkisel tarama modeli ile araştırma gerçekleştirilmiştir.

\section{Araştırma Grubu}

Araştırma grubu 2014-2015 eğitim öğretim yılında Ankara ilinde Sincan ilçesinde bulunan dört faklı okul türünde (Anadolu Lisesi, Endüstri Meslek Lisesi, Ticaret Meslek Lisesi, Kız Meslek Lisesi) öğrenimlerine devam etmekte olan 358 öğrenciden oluşmaktadır. Bu öğrenciler, dört farklı okul türünde okuyan 9. 10. ve 11. Sınıftaki öğrencilerden elverişli örnekleme yoluyla seçilmiştir. Bu öğrencilerin 183'ü erkek (\%51.1) ve 175'i kız (\%48.9) dır. Veriler sınıf ortamında yaklaşık 35 dakikada araşttrmacı tarafindan toplanmıştır. Katılım gönülü̈lük esasına göre gerçekleştirilmiştir. Toplam 400 katılımcıdan elde edilen verilerden eksik ve hatalı olanlar değerlendirmeye alınmayarak 358 katılımcının verileri incelenmiştir. Öğrencilerin Kişisel bilgi formuna verilen cevapların analiz sonucu Tablo 1'de gösterilmiştir. 
Tablo 1. Katılımcılarla İlgili Cinsiyet, Sınıf Düzeyi, Okul Türüne İlişkin Değerlerin Dağılımı

\begin{tabular}{|c|c|c|c|c|}
\hline \multirow{4}{*}{ Değişkenler } & \multicolumn{2}{|c|}{ Cinsiyet } & $\mathrm{n}$ & $\%$ \\
\hline & \multicolumn{2}{|c|}{$\mathrm{K} ı \mathrm{z}$} & 175 & 48.9 \\
\hline & \multicolumn{2}{|c|}{ Erkek } & 183 & 51.1 \\
\hline & \multicolumn{2}{|c|}{ Toplam } & 358 & 100 \\
\hline Sinıf & Kız & Erkek & & \\
\hline 9.sınıf & 80 & 70 & 150 & 41.9 \\
\hline 10.sınıf & 25 & 71 & 96 & 26.8 \\
\hline 11.sınıf & 70 & 42 & 112 & 31.3 \\
\hline \multicolumn{5}{|l|}{ Okul Türü } \\
\hline Anadolu Lisesi & 77 & 65 & 142 & 39.7 \\
\hline Ticaret Meslek Lisesi & 11 & 24 & 35 & 9.8 \\
\hline Kız Meslek Lisesi & 78 & 0 & 78 & 21.8 \\
\hline Endüstri Meslek Lisesi & 9 & 94 & 103 & 28.7 \\
\hline
\end{tabular}

Tablo 2. Katılımcıların İnternet Kullanım Amaçlarının Dağılımı

\begin{tabular}{|c|c|c|c|c|}
\hline \multirow{15}{*}{$\begin{array}{l}\text { İnternet Kullanım } \\
\text { Amaçları }\end{array}$} & Seçenekler & Yanitlar & $f$ & $\%$ \\
\hline & \multirow{2}{*}{ Mail- İletişim } & Evet & 108 & 30.3 \\
\hline & & Hayır & 249 & 69.7 \\
\hline & \multirow{2}{*}{ Film- Video- Müzik } & Evet & 235 & 65.6 \\
\hline & & Hayır & 122 & 34.2 \\
\hline & \multirow{2}{*}{ Haber } & Evet & 86 & 24.1 \\
\hline & & Hayır & 271 & 75.9 \\
\hline & \multirow{2}{*}{ Oyun } & Evet & 265 & 74.2 \\
\hline & & Hayır & 92 & 25.8 \\
\hline & \multirow{2}{*}{ Sosyal ağlar } & Evet & 256 & 71.7 \\
\hline & & Hayır & 101 & 28.3 \\
\hline & \multirow{2}{*}{ Sohbet } & Evet & 198 & 55.5 \\
\hline & & Hayır & 159 & 44.5 \\
\hline & \multirow{2}{*}{ Araşttrma-ödev } & Evet & 265 & 74.2 \\
\hline & & Hayır & 92 & 25.8 \\
\hline
\end{tabular}

Tablo 3. Katılımcıların İnternet Erişim İmkanlarının Dağılımı

\begin{tabular}{llccc}
\hline & Seçenekler & Yanıtlar & f & \% \\
\cline { 2 - 5 } & \multirow{2}{*}{ Ev } & Evet & 276 & 77.1 \\
& \multirow{3}{*}{ Okul } & Hayır & 82 & 22.9 \\
İnternet & Erişim & Evet & 41 & 11.5 \\
İmkanları & \multirow{2}{*}{ İnternet kafe } & Hayır & 317 & 88.5 \\
& & Evet & 34 & 9.5 \\
& \multirow{3}{*}{ Kütüphane } & Hayır & 324 & 90.5 \\
& & Evet & 4 & 1.1 \\
& \multirow{3}{*}{ Cep telefonu } & Hayır & 354 & 98.9 \\
& & Evet & 279 & 77.9 \\
& & Hayır & 79 & 22.1 \\
\hline
\end{tabular}

\section{Veri Toplama Araçları}

Araştırma verileri, araştırmacının kendisi tarafindan hazırlanmış olan katılımcı bilgi formu, internet bağımlılığı ölçeği (iBÖ) ve algılanan sosyal destek ölçeği(ASDÖ-R) uygulanarak toplanmıştr.

\section{Katilımcı bilgi formu}

Bu formda öğrencilere ait demografik bilgiler ile kişisel bilgisayara sahip olup olmadığı, internete bağlandığı yer, ailenin internet kullanımı müdahalesi, günlük internet kullanım süre ve amacı ile son dönem not ortalaması, soruları yer almaktadır. 
Internet bağımlılığı ölçeği (iBÖ)

Young (1998) tarafindan Ruhsal Bozuklukların Tanısal ve Sayımsal El Kitabı-4 (DSM-IV)'ün “Psikoaktif Madde BağımIılığı" ölçütlerinden uyarlanarak oluşturulmuş ve Bayraktar (2001) tarafindan Türkçeye uyarlanmıştr. 12-17 yaş grubuna uygun 20 maddelik Likert tarzı bir ölçektir. Kathlımcıların "Hiçbir zaman" "Nadiren" "Arada sırada" "Çoğunlukla" "Çok sık" ile "Devamlı" seçeneklerinden bir tanesini işaretlemeleri gerekmektedir. Bu seçeneklere sırasıyla 01234 ve 5 puan verilmektedir. Young (1998) tarafindan Ölçekten 50 puan ve altında alan bireyler "Semptom Göstermeyenler", 50-79 aralığında puan alan bireyler "Sınırlı Semptom Gösterenler" ve ölçekten 80 ile üzeri alan bireyler "Patolojik İnternet Kullanıcısı" şeklinde sınıflandırılmıştr. İnternet Bağımlılı̆ı Ölçeği'nin Spearman-Brown değeri açısından güvenirliği .87 'dir ve Alpha değeri açısından güvenirliği ise .91 olarak belirlenmiştir. Bu araştırmada da ölçeğin Cronbach Alpha güvenirlik katsayısı 0.90 olarak tespit edilmiştir.

Araştırmada kullanılan tek faktörlü İnternet Bağımlılı̆ı Ölçeğinin faktör yapısının aynı şekilde olup olmadığını test etmek amacıyla doğrulayıı faktör analizi (DFA) yöntemi kullanılmıştır. DFA toplanan 358 kişilik veri üzerinde uygulanmıştr. İlgili analiz LISREL 8.72 paket programı kullanılarak analiz edilmiştir. Ölçekteki maddelerin Likert tipi maddelerden oluşmasından dolayı model parametre kestirimlerinde maksimum olabilirlik yöntemi kullanılmıştır (Jöreskog \& Sörbom, 2004). Ölçeğin bir boyutlu yapısını test etmek için yapılan doğrulayıcı faktör analizi sonucunda oluşan model yapısı Şekil 1'de gösterilmiştir.

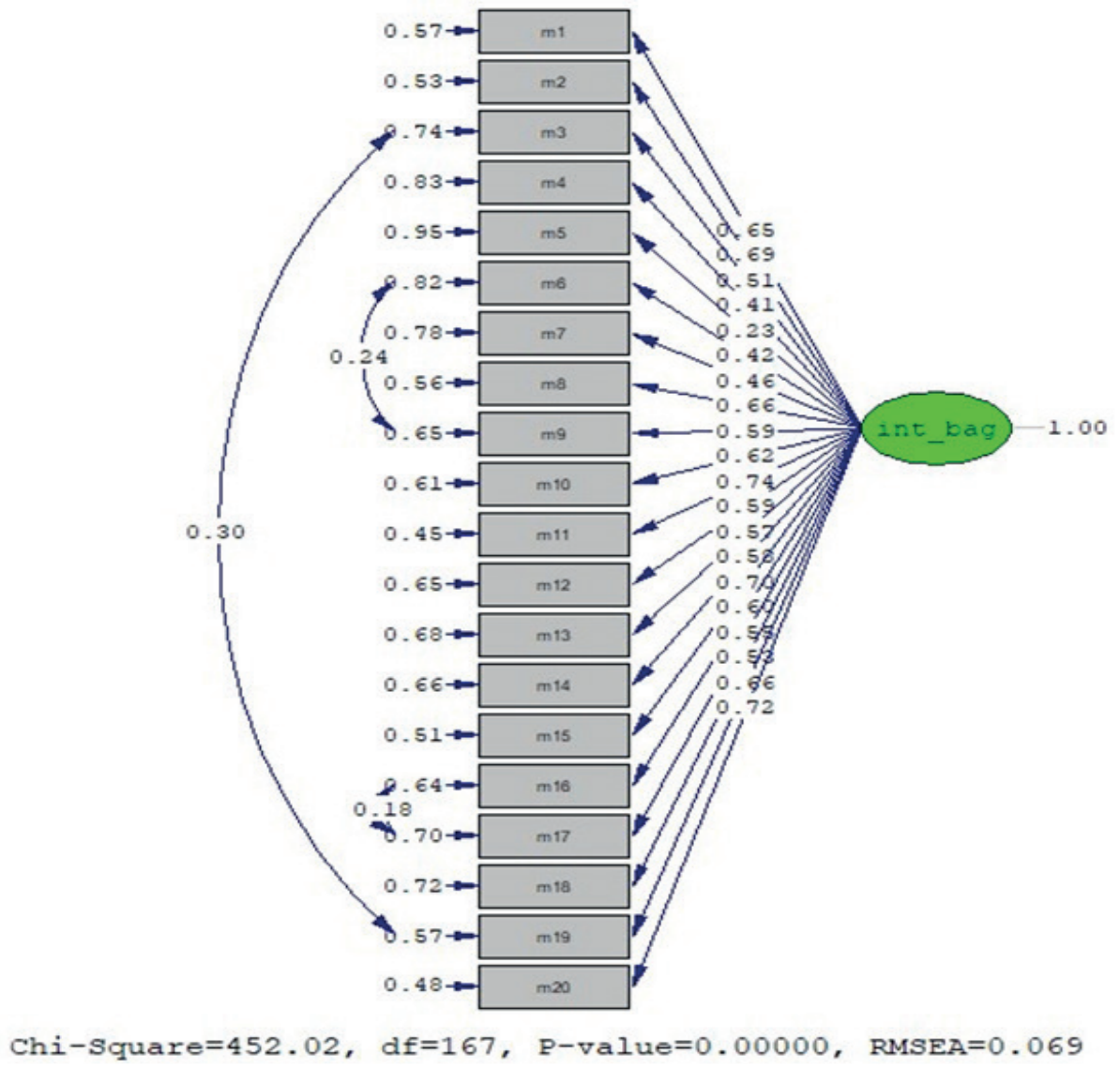

Şekil 1. İnternet Bağımlıı̆̆ı Ölçeğinin Tek Boyutlu Doğrulayıcı Faktör Analiz Modeli

Ölçeğin bir boyutlu yapısına ilişkin elde edilen modele ilişkin model-veri uyum ve uyumsuzluk indeksleri ve bu değerlere ilişkin kesme puan değerleri Tablo 4'te gösterilmiştir.

Tablo 4. İnternet Bağımlılığı Ölçeğinin Tek Boyutlu Yapısına İlişkin Model Veri Uyum ve Uyumsuzluk İndeksleri

\begin{tabular}{ccccccccc}
\hline $\mathrm{x}^{2} / \mathrm{sd}$ & $\mathrm{GFI}$ & $\mathrm{AGFI}$ & $\mathrm{NFI}$ & $\mathrm{CFI}$ & IFI & RFI & RMSEA & SRMR \\
\hline 2.70 & 0.90 & 0.86 & 0.95 & 0.97 & 0.97 & 0.94 & 0.069 & 0.049 \\
\hline
\end{tabular}

Tablo 4'e göre $x^{2} / s d=2.70 ; \mathrm{GFI}=0.90 ; \mathrm{AGFI}=0.86 ; \mathrm{NFI}=0.95 ; \mathrm{CFI}=0.97 ; \mid F I=0.97 ; \mathrm{RFI}=0.94 ; \mathrm{RMSEA}=0.069$ ve SRMR $=0.049$ olduğu görülmektedir. Schermelleh-Engel-Moosbrugger (2003) $x^{2} / s d$ değerinin 2'den, RMSEA değerinin 
0.05'ten ve SRMR değerinin 0.05'ten küçük; GFI ve NFI değerlerinin 0.95 ile 1.00, AGFI ve RFI değerinin 0.90 ile 1.00

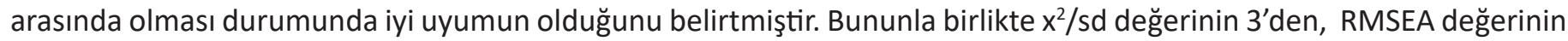
0.08'den ve SRMR değerinin 0.1'den küçük; GFI ve NFI değerlerinin 0.90 ile 0.95 AGFI ve RFI değerinin 0.85 ile 0.90 arasında olması durumunda ise kabul edilebilir uyuma işaret etmektedir. Bu kapsamda İnternet Bağımlılı̆ı Ölçeği'nin tek boyutlu yapısına göre kurulan modelin NFI, CFI, RFI değerlerinin iyi uyum kalan diğer indekslere göre ise kabul edilebilir uyum gösterdiği görülmektedir. Buna göre ölçeğin 20 maddeden oluşan tek boyutlu yapısını koruduğu görüldüğünden araştırmada öğrencilerin internet bağımlılığını değerlendirmede uygun olduğu söylenebilir.

\section{Algılanan sosyal destek ölçeği}

Yıldırım (1997) tarafindan geliştirilen Algılanan Sosyal Destek Ölçeğinin yine Yıldırım (2004) tarafindan revize edilmiş hali olan (ASDÖ-R) araştırmada bireylerin sosyal destek algılarını ölçmek için kullanılmıştır. ASDÖ-R'nin alt ölçeklerine bakıldığında üç alt boyutu bulunduğu görülmektedir. Bunlar: Aile Desteği (AID), Arkadaş Desteği (ARD) ve Öğretmen Desteği (ÖĞD)'dir. ASDÖ-R'nin alt ölçeklerinde sırasıyla 20 (AID), 13 (ARD) ve 17 (ÖĞD) madde, ölçek toplamında ise 50 madde yer almaktadır. Üç derecelendirmeli (bana uygun=3, kısmen=2, bana uygun değil=1) likert tipi bir ölçektir. Alt ölçeklerin her birinde birer tane tersine çevrilmiş, toplamda 3 tane tersine çevrilmiş madde yer almaktadır. Ölçeklerden alınacak puan aralıkları şu şekildedir : ARD; 13-39, ÖĞD ; 17-51, Aid; 20-60, toplam ASDÖ-R ; 50-150. Ölçekten alınan yüksek puan bireyin daha çok sosyal destek aldığını göstermektedir. Ölçeğin tümü için Alpha = .93, rxx = .91; AiD için Alpha = .94, rxx = .89; ARD için Alpha = .91, rxx = .85; ÖĞD için Alpha = .93, rxx = .86 bulunmuştur. Ölçeğin tespit edilen güvenirlik katsayıları ölçeğin tamamının ve alt ölçeklerinin sosyal desteği ölçmede güvenilir olduğunu ortaya koymaktadır (Yıldırım, 2004). Bu araştırmada ASDÖ-R aile desteği boyutunun Cronbach Alfa katsayısı 0.91, öğretmen desteği boyutunun 0.92 ve arkadaş desteği boyutunun 0.89 , ölçeğin tümü için Cronbach Alfa katsayısı 0.93 olarak hesaplanmıştır. Bu sonuçlar ölçeğin geçerli ve güvenilir olduğunu göstermektedir.

\section{Verilerin Analizi}

Verilerin istatistiksel analizleri için SPSS 11.5 kullanılmıştır. Demografik veriler için betimsel istatistiklerden yararlanılmıştır. Öğrencilerin internet bağımlılık düzeylerinin çeşitli değişkenlere (cinsiyet, gelir durumu, anne eğitim düzeyi, baba eğitim düzeyi ve akademik başarı) göre anlamlı bir farklılık gösterip göstermediğini Ki-Kare Testi ile algılanan sosyal destek puanlarının internet bağımlılık düzeylerine göre farklı olup olmadığı ise T Testi ile test edilmiştir. Araştırmanın istatistiksel anlamlılık sınırı $p<0,05$ olarak kabul edilmiştir.

\section{Bulgular}

Öğrencilerin internet bağımlılık düzeylerinin dağılımı Tablo 4'te verilmiştir.

Tablo 5. Katılımcıların İnternet Bağımlılık Puanları

\begin{tabular}{|c|c|c|c|c|c|}
\hline \multicolumn{2}{|c|}{$\begin{array}{l}\text { İÖ puanı } \geq 80 \\
\text { (patolojik kullanım) }\end{array}$} & \multicolumn{2}{|c|}{$\begin{array}{c}79 \geq \text { їÖ puanı } \geq 51 \\
\text { (sınırlı semptom ) }\end{array}$} & \multicolumn{2}{|c|}{$\begin{array}{c}\text { İÖ puanını } \leq 50 \\
\text { (semptom yok) }\end{array}$} \\
\hline$n$ & $\%$ & $n$ & $\%$ & $n$ & $\%$ \\
\hline 3 & 0.8 & 53 & 14.8 & 302 & 84.4 \\
\hline
\end{tabular}

Araştırma grubunda patolojik düzeyde internet kullanımı yalnızca 3 öğrencide belirlenmiştir. Bu nedenle anlamlı istatistiksel bir karşılaştırma yapabilmek için patolojik internet kullanıcısı (IBÖ puanı 80 ve üzeri) olanlar ile sınırlı semptom gösterenler (IBÖ puanı 51-79 arasında olanlar) birleştirilerek "semptom gösterenler" olarak tanımlanmıştır. Böylece karşılaştırma, "semptom göstermeyenler" ile "semptom gösterenler" şeklinde iki düzey arasında yapılmıştır. Yeni tanımlamaya ilişkin veriler Tablo 6'da gösterilmiştir.

Tablo 6. Katılımcıların İnternet Bağımlılık Düzeyleri

\begin{tabular}{|c|c|c|c|}
\hline \multicolumn{2}{|c|}{$\begin{array}{l}\text { Bağımlılık semptomu gösterenler } \\
\qquad(\text { (ІВÖ > 50) }\end{array}$} & \multicolumn{2}{|c|}{$\begin{array}{l}\text { Bağımlılık semptomu } \\
\text { göstermeyenler } \\
\text { (івÖ } \leq 50 \text { ) }\end{array}$} \\
\hline$n$ & $\%$ & $n$ & $\%$ \\
\hline 56 & 15.6 & 302 & 84.4 \\
\hline
\end{tabular}


Cinsiyete Göre İnternet Bağımlılığına İlişkin Bulgular

Cinsiyet ile İÖ’den elde edilen puanlar arasında istatistiksel olarak anlamlı bir farklılık olup olmadığını belirlemek amacıyla Ki-Kare Testi yapılmıştır. Sonuçlar Tablo 7'de verilmiştir.

Tablo7. Cinsiyete Göre їB̈ puanlarına ilişkin Ki-Kare Testi Sonuçları

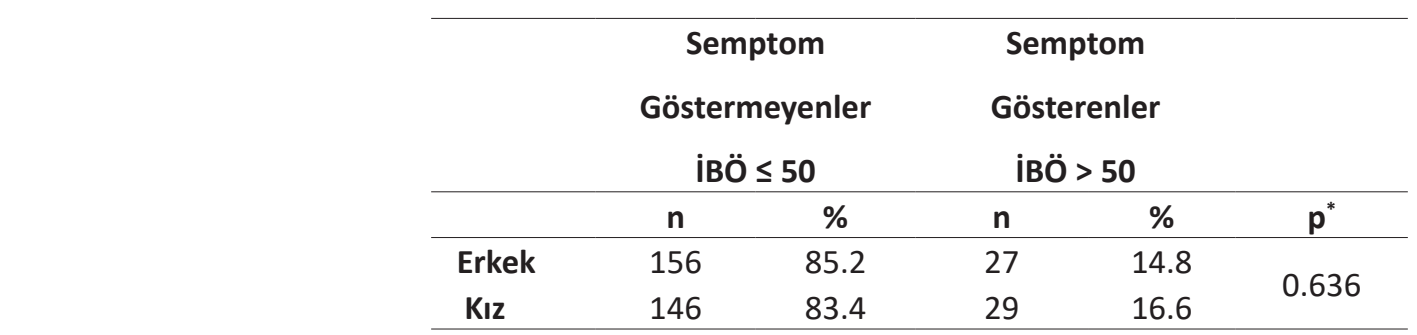

${ }^{*} p<0,05$

Analiz sonuçları cinsiyete göre internet bağımlılığı semptomunda anlamlı bir fark olmadığına işaret etmektedir. Yani ölçek puanlarının 50'nin altında ya da 50'nin üstünde olma oranları arasında kız ve erkek öğrenciler arasında fark bulunmamaktadır( $p>0.05)$. Öğrencilerin cinsiyetleri internet bağımlılık düzeyleri açısından anlamlı bir fark oluşturmamaktadır.

İnternet Bağımlılığının Aile Gelir Düzeyine Göre İncelenmesine ilişkin Bulgular

Tablo 8. Aile Gelir Düzeyine Göre İBÖ Puanlarına İlişkin Ki-Kare Testi Sonuçları

\begin{tabular}{|c|c|c|c|c|c|c|}
\hline & \multicolumn{2}{|c|}{$\begin{array}{c}\text { Semptom } \\
\text { Göstermeyenler } \\
\text { івÖ } \leq 50\end{array}$} & \multicolumn{2}{|c|}{$\begin{array}{c}\text { Semptom } \\
\text { Gösterenler } \\
\text { IBÖ > } 50\end{array}$} & \multirow[b]{2}{*}{$\mathbf{p}^{*}$} & \multirow[b]{2}{*}{ Contingency Coefficient } \\
\hline & $\mathrm{n}$ & $\%$ & $n$ & $\%$ & & \\
\hline 4500 TL den fazla & 17 & 70.8 & 7 & 29.2 & \multirow{4}{*}{0.038} & \multirow{4}{*}{0.152} \\
\hline 3000-4500 TL arası & 48 & 85.7 & 8 & 14.3 & & \\
\hline 1300-3000 TL arası & 210 & 87.1 & 31 & 12.9 & & \\
\hline 1300 TL den az & 27 & 73 & 10 & 27 & & \\
\hline
\end{tabular}

Tablo 8 incelendiğinde öğrencilerin aile gelir düzeyinin internet bağımlılığı "semptom gösterenler" ve "semptom göstermeyenler" oranları arasında istatistiksel olarak anlamlı bir fark oluşturduğu görülmektedir $(p<0.05)$. Veriler incelendiğinde aile gelir düzeyi 1300 TL den az olan öğrenciler ile aile gelir düzeyi 1300-3000 TL arasında olan öğrencilerini ІВÖ puanının 50'nin üstünde olma yüzdeleri arasında anlamlı fark bulunduğu anlaşılmaktadır $(p<0.05)$. Aynı şekilde ailesinin gelir düzeyi 4500 TL den fazla olan öğrenciler ile gelir düzeyi 1300-3000 TL arasında olan öğrencilerin puanının 50 ’nin üstünde olma yüzdesi arasında da istatistiksel olarak anlamlı fark görülmektedir ( $p<0.05)$.

Başka bir ifadeyle araştırma grubunda gelir düzeyi 1300-3000 TL aralığında olan aileler orta gelir düzeyi olarak kabul edildiklerinde, öğrencinin ailesinin ortalamanın altında ya da üstünde gelire sahip olmasının bağımlılık semptomlarının görülüp görülmemesinde öğrenciler arasında önemli bir farklılık oluşturduğu sonucuna ulaşılmaktadır. Ortalamanın altında ya da üstünde gelir düzeyine sahip ailelerden gelen öğrencilerde orta gelir düzeyindeki öğrencilere kıyasla daha çok internet bağımlılık semptomu görülmüştür.

\section{İnternet Bağımlılığının Anne-Baba Eğitim Düzeyine Göre İncelenmesine İlişkin Bulgular}

Anne eğitim düzeyi ve baba eğitim düzeyine göre öğrencilerin İBÖ’den aldıkları puanlara ilişkin Ki-Kare Testi sonuçları ayrı tablolar halinde Tablo 9 ve Tablo 10'da verilmiştir. 
Tablo 9. Anne Eğitim Düzeyine Göre İBÖ Puanlarına İlişkin Ki-Kare Testi Sonuçları

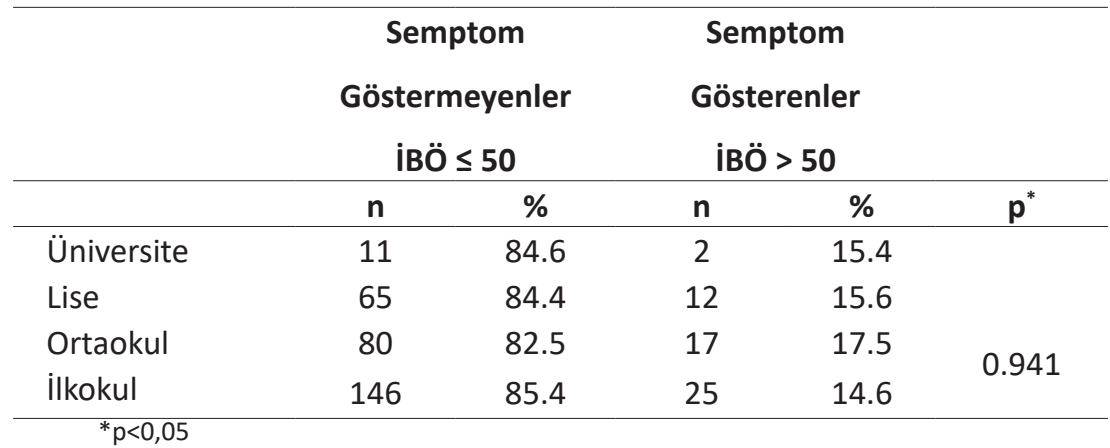

Tablo 9'da görüldüğü gibi Ki kare testi sonuçlarına göre anne eğitim düzeyine göre öğrencilerin internet bağımlılığı "semptom gösterenler" ve "semptom göstermeyenler" oranlarında istatistiksel olarak anlamlı bir fark yoktur ( $p>0.05)$. İnternet bağımlıı̆̆ı semptomu gösterip göstermemesinde öğrencilerin, anne eğitim düzeyinin farklılaşması önemli bir farklıık oluşturmamaktadır.

Tablo 10. Baba Eğitim Düzeyine Göre ïÖ Puanlarına İlişkin Ki-Kare Testi Sonuçları

\begin{tabular}{|c|c|c|c|c|c|}
\hline & \multicolumn{2}{|c|}{$\begin{array}{c}\text { Semptom } \\
\text { Gösterenler } \\
\text { івÖ > } 50\end{array}$} & \multicolumn{2}{|c|}{$\begin{array}{c}\text { Semptom } \\
\text { Göstermeyenler } \\
\text { IBÖ } \leq 50\end{array}$} & \multirow[b]{2}{*}{$\mathbf{p}^{*}$} \\
\hline & $\mathrm{n}$ & $\%$ & $n$ & $\%$ & \\
\hline Üniversite & 5 & 10.2 & 44 & 89.9 & \multirow{4}{*}{0.091} \\
\hline Lise & 20 & 18 & 91 & 82 & \\
\hline Ortaokul & 21 & 21.4 & 77 & 78.6 & \\
\hline ilkokul & 10 & 10 & 90 & 90 & \\
\hline
\end{tabular}

Tablo 10'da görüldüğü gibi Ki kare testi sonuçlarına göre baba eğitim düzeyine göre öğrencilerin internet bağımlılığı "semptom gösterenler" ve "semptom göstermeyenler" oranlarında istatistiksel olarak anlamlı bir fark yoktur ( $p>0.05$ ). İnternet bağımlıı̆ı semptomu gösterip göstermemesinde öğrencilerin baba eğitim düzeyinin farklılaşması önemli bir farklılık oluşturmamaktadır.

İnternet Bağımlılığının Algılanan Sosyal Destek Durumuna Göre İncelenmesine ilişkin Bulgular

Tablo 11. İnternet Bağımlıı̆ı̆ı Düzeylerine Göre Aileden Algılanan Sosyal Destek Puanlarına İlişkin T Testi Sonuçları

\begin{tabular}{|c|c|c|c|c|c|c|c|c|}
\hline & \multicolumn{8}{|c|}{ ASDÖR AILE } \\
\hline & Ortalama & Standart & & & Çarpıklık & Basıklık & & \\
\hline & & Sapma & Min & Max & (Skewness) & (Kurtosis) & $t$ & $\mathbf{p}^{*}$ \\
\hline $\begin{array}{l}\text { Semptom Gösterenler } \\
\text { İB̈ > } 50\end{array}$ & 49.68 & 8.42 & 29 & 59 & -1.013 & 0.045 & & \\
\hline $\begin{array}{l}\text { Semptom Gösterme- } \\
\text { yenler }\end{array}$ & & & & & & & -2.463 & 0.014 \\
\hline івӦ $\leq 50$ & 52.30 & 7.11 & 25 & 60 & -1.535 & 2.319 & & \\
\hline
\end{tabular}

Tablo 11'de görüldüğü gibi, İnternet bağımlılığı "semptom gösterenler" ve "semptom göstermeyenler" ile Algılanan Sosyal Destek Ölçeği (ASDÖ-R)'nin aile alt boyut puan ortalamaları arasında anlamlı fark vardır $(p<0.05)$. Internet bağımlılığı semptomu göstermeyenlerin ASDÖ-R aile puan ortalaması internet bağımlılı̆ı semptomu gösterenlere göre anlamlı düzeyde yüksektir. 
Tablo 12. İnternet Bağımlılığı Düzeylerine Göre Arkadaştan Algılanan Sosyal Destek Puanlarına ilişskin T Testi Sonuçları

\begin{tabular}{|c|c|c|c|c|c|c|c|c|}
\hline & \multicolumn{8}{|c|}{ ASDÖR ARKADAŞ } \\
\hline & Ortalama & Standart & & & Çarpıklık & Basıklık & & \\
\hline & & Sapma & Min & Max & (Skewness) & (Kurtosis) & $\mathrm{t}$ & $\mathrm{p}^{*}$ \\
\hline Semptom Gösterenler & 33.71 & 5.35 & 17 & 39 & -1.245 & 1.220 & & \\
\hline $\begin{array}{l}\text { İÖ > } 50 \\
\text { Semptom Gösterme- } \\
\text { yenler }\end{array}$ & & & & & & & -1.102 & 0.271 \\
\hline їВ̈ $\leq 50$ & 34.52 & 4.97 & 15 & 39 & -1.494 & 2.034 & & \\
\hline
\end{tabular}

Tablo 12 incelendiğinde "semptom gösteren" ve "semptom göstermeyen" öğrencilerin ASDÖ-R arkadaş puan ortalamaları arasında anlamlı fark olmadığı anlaşılmaktadır ( $p>0.05)$.

Tablo 13. İnternet Bağımlılığı Düzeylerine Göre Öğretmenden Algılanan Sosyal Destek Puanlarına ilişkin T Testi Sonuçları

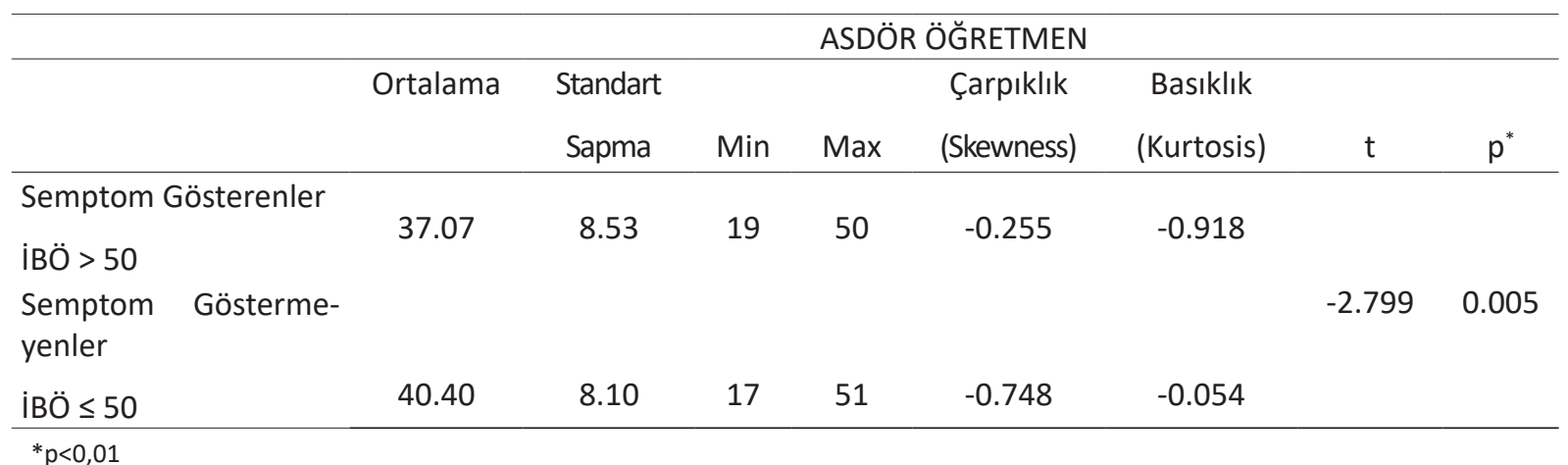

Tablo 13 incelendiğinde "semptom gösteren" ve "semptom göstermeyen" öğrencilerin ASDÖ-R öğretmen puan ortalamaları arasında anlamlı fark bulunduğu anlaşılmaktadır $(p<0.01)$. İnternet bağımlıı̆ı̆ semptomu göstermeyen öğrencilerin ASDÖ-R öğretmen puan ortalaması internet bağımlılığı semptomu bulunan öğrencilere kıyasla anlamlı şekilde yüksek tespit edilmiştir.

\section{İnternet Bağımlılığının Akademik Başarıya Göre İncelenmesine illişkin Bulgular}

Araştırma grubundaki öğrencilerin akademik başarı düzeyleri ortaöğretim not sistemine göre belirlenmiştir. Öğrencilerin son dönem not ortalamaları akademik başarı tespitinde değerlendirmeye alınmıştır. Not ortalaması dağııımına ilişkin veriler Tablo 14'te gösterilmektedir.

Tablo 14. Öğrencilerinin Akademik Başarı Düzeyleri Dağılımı

\begin{tabular}{llcc}
\hline \multicolumn{2}{c}{ Son dönem not ortalaması } & $\mathrm{n}$ & $\%$ \\
\hline $85-100$ & (pekiyi) & 19 & 5.3 \\
$70-84,9$ & ('lyi ) & 144 & 40.2 \\
$60-69,99$ & (orta) & 105 & 29.3 \\
$50-59,99$ & (Geçer) & 60 & 16.8 \\
$0-49,99$ & (Geçmez) & 30 & 8.4 \\
\hline
\end{tabular}


Tablo 15. Akademik Başarı Düzeyine Göre ïÖ Puanlarına Iliş̧in Ki-Kare Testi Sonuçları

\begin{tabular}{|c|c|c|c|c|c|}
\hline \multirow[b]{2}{*}{ Not Ortalamaları } & \multicolumn{2}{|c|}{$\begin{array}{c}\text { Semptom } \\
\text { Göstermeyenler } \\
\text { івÖ } \leq 50\end{array}$} & \multicolumn{2}{|c|}{$\begin{array}{c}\text { Semptom } \\
\text { Gösterenler } \\
\text { İÖ > } 50\end{array}$} & \multirow[b]{2}{*}{$\mathbf{p}^{*}$} \\
\hline & $\mathrm{n}$ & $\%$ & $\mathrm{n}$ & $\%$ & \\
\hline 85-100 (pekiyi) & 17 & 89.5 & 2 & 10.5 & \multirow{5}{*}{0.568} \\
\hline 70-84,9 (İyi ) & 124 & 86.1 & 20 & 13.9 & \\
\hline 60-69,99 (orta) & 90 & 85.7 & 15 & 14.3 & \\
\hline 50-59,99 (Geçer) & 47 & 78.3 & 13 & 21.7 & \\
\hline 0-49,99 (Geçmez) & 24 & 80 & 6 & 20 & \\
\hline
\end{tabular}

Tablo 15 incelendiğinde öğrencilerin akademik başarıları ile internet bağımlılı̆̆ı "semptom gösterenler" ve "semptom göstermeyenler" oranları arasında istatistiksel olarak anlamlı fark bulunmadığı anlaşılmaktadır ( $p>0.05)$.

\section{Sonuçlar}

Araştırma bulguları lise öğrencilerinin cinsiyetlerine göre internet bağımlılık düzeyleri arasında anlamlı bir fark bulunmadığını ortaya koymaktadır. Alanyazına bakıldığında çoğu araştırmada internet bağımlılı̆ının erkeklerde kızlara göre daha fazla tespit edildiği görülmektedir (Bayraktar, 2001; Cao ve Su, 2007; Gününç, 2009; Gürcan, 2010; Morahan-Martin ve Schumacher, 2000; Yang ve Tung, 2007). Daha az sayıda olmakla beraber araştirma sonucuna benzer şekilde internet bağımlılığııın cinsiyete göre farklılık göstermediğini belirleyen araştırmalar mevcuttur. (Bayraktar ve Gün, 2007; Ceyhan, 2011; Jang, Hwang ve Coi, 2008; Pawlak, 2002). Araştrmadaki bu farklılığın internete erişim imkanlarının artması ve internet kullanımının giderek yaygınlaşması (TÜiK, 2013, 2014, 2015, 2016, 2017, 2018) ile bağlantılı olduğu düşünülmektedir. Araştırmada öğrencilerin internete erişim imkanları da incelenmiştir ve elde edilen bulgular öğrencilerin evden internete bağlanma oranının \%77,1 ve cep telefonundan internete bağlanma oranının ise $\% 77,9$ olduğunu göstermektedir. Bu veriler de öğrencilerin gerek ev gerekse dışarıda internete kolaylıkla ulaşabildiklerini göstermektedir.

Araştırmanın bir diğer bulgusu lise öğrencilerinin internet bağımlılık semptomu gösterip göstermemesinde aile gelir düzeyinin önemli bir faktör olduğunu ortaya koymaktadır. Araştırmada ortalamanın altında ya da üstünde gelir düzeyine sahip ailelerden gelen öğrencilerin daha fazla internet bağımlıık semptomu gösterdikleri belirlenmiştir. Alanyazında bu konuda araştırmalar arasında farklı bulguların olduğu görülmektedir. İnternet bağımlılı̆̆ı ile sosyo-ekonomik düzey arasında anlamlı bir ilişki bulunmadığını belirleyen araştırmalara (Balcı ve Gülnar, 2009; Balta ve Horzum, 2008; Esen ve Siyez, 2011; İnan, 2010; Zorbaz, 2013) karşın sosyo-ekonomik düzey arttkça internet bağımlılığının arttığını belirleyen araştırma sonuçları (Batgün ve Kılıç, 2011; Gününç, 2009; Tanrıverdi, 2012) mevcuttur. Benzer şekilde Ulutaşdemir, Verim, Bakır ve Deniz (2017) sağıık bilimleri fakültesi ve tı fakültesinde okuyan 286 öğrenciyle gerçekleştirdikleri araştırmada sosyoekonomik düzey arttkça internet kullanımının arttğını belirlemişlerdir.

İnternet bağımlılı̆ı ile gelir düzeyi ilişkisine dair araştırmalar arasındaki farkın internet kullanımının giderek yaygın ve kolay hale gelmesi, internete erişim imkanlarının artması ve maliyetin ucuzlaması gibi nedenlerle gelir durumundan bağımsız olarak internete erişim firsatlarıyla bağlantılı olduğu düşünülmektedir. Nitekim bu araştırmada da öğrencilerin gelir durumlarına bakıldığında aile gelir düzeyi 1300-3000 TL arasında olan öğrencilerin sayısı 241 (\%67,3), aile gelir düzeyi 4500 TL'den fazla olan öğrencilerin sayısı ise $24(\% 6,7)$ kişi olarak belirlenmiştir. Ancak internete erişim imkanlarına bakıldığında öğrencilerin internete erişim kaynaklarının sırasıyla; cep telefonu (\%77,9), ev (\%77,1), okul (\%11,5), internet kafe $(\% 9,5)$ ve kütüphane $(\% 1,1)$ olduğu görülmektedir (Bakınız Tablo 3). Bu durumun öğrencilerin teknolojiye ve internete erişim firsatlarına ek olarak teknolojiye ve internete erişim maliyetinin uygun oluşu ile bağlantılı olduğu düşünülmektedir.

Araştırmada öğrencilerinin anne ve baba eğitim düzeylerinin internet bağımlılığı açısından anlamlı bir farklılık oluşturmadığı belirlenmiştir. Bu bulgular alanyazın ile benzerlik göstermektedir (Gününç, 2009; Üneri ve Tanıdır, 2011; Günbatar ve Gökçearslan, 2012).

Araştırmada lise öğrencilerinin son dönem not ortalamalarına göre internet bağımlılığı semptomları arasında anlam- 
Iı bir farklılık bulunmadığı tespit edilmiştir. Alanyazına bakıldı̆ında internet aşırı kullanımı ile okul/ders başarısı arasında anlamlı bir ilişki bulunduğunu ortaya koyan araştırmalar mevcuttur (Alaçam, 2012; Cengizhan, 2005; Toraman, 2013). İmpraim (2012)'in lise öğrencileriyle gerçekleştirdiği bir çalışmada 370 lise öğrencisi çalışma grubuna dahil edilmiş ve çalışma sonucunda akademik performans ile internet bağımlıı̆̆ arasında anlamlı bir ilişki olmadığına ulaşılmıştır. Aslında internet doğru ve bilinçli şekilde kullanıldığında akademik başarıyı olumsuz etkilemediği gibi aksine, öğrencinin ders başarısına katkıda bulunabilmektedir (Makas, 2008). Lise öğrencileri ile yürütülen bu araştırmada, öğrencilerin not ortalamaları ile internet bağımlılı̆ı semptomları arasında anlamlı bir fark olmadığı bulgusu bu bağlamda öğrencilerin interneti yalnızca oyun ve sosyal ağlar için değil aynı zamanda ödev ve araştırma amacıyla kullanmaları ile bağlantlı görünmektedir ( Bakınız Tablo 2, Tablo3).

Araştırma bulgularına göre Algılanan sosyal destek ölçeği alt boyutları incelendiğinde internet bağımlılığı semptomu bulunmayan öğrencilerin hem aile hem de öğretmen sosyal destek puanları diğer gruba göre (semptom gösterenler) anlamlı düzeyde yüksek olarak belirlenmiştir. İnternet bağımlılığı görülen ve internet bağımlılığı görülmeyen öğrenciler arasında ölçeğin arkadaş alt boyut puanlarında anlamlı bir fark bulunmadığı belirlenmiştir. Algılanan sosyal destek toplam puan ortalamaları incelendiğinde öğrencilerin internet bağımlılı̆̆ı semptomu gösterip göstermemesine göre ASDÖ-R toplam puan ortalamalarının anlamlı olarak farklılaşthğı görülmektedir. İnternet bağımlılığı semptomu bulunmayan öğrencilerin algılanan sosyal destek toplam puanları anlamlı düzeyde yüksek bulunmuştur Araştırmanın algılanan sosyal destek ve internet bağımlıı̆ı̆na dair bulguları alanyazın ile karşılaştıııldığında sonuçların benzerlik gösterdiği görülmektedir. Ak (2014) tarafindan mesleki ve teknik eğitim kurumu öğrencileri ile yürütülen çalışmada öğrencilerin internet kullanım alışkanlıklarıyla ailelerinden algıladıkları sosyal destek puan ortalamaları arasında anlamlı düzeyde ve negatif yönde ilişki olduğu belirlenmiştir. Aynı şekilde Pawlak (2002) lise öğrencileri ile yaptığı bir çalışmasında yalnızlık ile sosyal desteğin internet bağımlılığı ile bağlantılı olduğunu belirlemiştir. Esen (2010)'in yaptı̆̆ı çalışmada bu araştırmanın sonucuna benzer şekilde internet bağımlılığı ile arkadaş ve özel kişiden algılanan sosyal destek arasında anlamlı bir ilişki bulunamamıştr. Kıran-Esen ve Gündoğdu (2010) tarafindan yürütülen çalışmanın bulguları ise bu çalışmaya benzer şekilde aile ve öğretmen desteğinin internet bağımlılığı puanları ile tutarlılık gösterdiğini ve destek arttkça internet bağımlılığı puanlarının düştüğünü ortaya koymaktadır.

\section{5. Öneriler}

Araştırma bulguları lise öğrencilerinde internet bağımlılığı ile aile gelir düzeyi ve algılanan sosyal desteğin birbiriyle bağlantılı önemli değişkenler olduğunu ortaya koymaktadır. Bu bağlamda alanda çalışan uzmanların ergenlerin ihtiyaçlarını belirlemesi ile aile, öğretmen ve arkadaşlarıyla sağlıklı ilişkiler kurabilmelerini sağlayacak önleyici ve müdahale edici çalışmaların yararlı olabileceği düşünülmektedir. Aynı zamanda genç nüfusu fazla olan bir ülke olarak internet kullanım yaşının düşmesi ve internet erişim imkanlarının artmasını da göz önüne alarak internet bağımlılığı konusunda ergenleri olduğu kadar aileleri ve öğretmenleri de bilgilendirmek oldukça önemli görünmektedir. Bu doğrultuda okullarda internetin sağlıklı ve güvenli kullanımını hedefleyen güncel verilere dayalı eğitim ve rehberlik çalışmalarının düzenlenmesinin yararlı olacağı düşünülmektedir.

\section{Kaynakça}

Ak, H. (2014). Mesleki ve teknik eğitim kurumları öğrencilerinin internet kullanım alışkanlıkları ile algıladıkları sosyal destek arasındaki ilişkinin incelenmesi. Yayımlanmamış Yüksek Lisans Tezi, Yıldız Teknik Üniversitesi Sosyal Bilimler Enstitüsü, İstanbul.

Alaçam, H. (2012). Denizli bölgesi üniversite öğrencilerinde internet bağımılığının görülme sıklığı ve yetişkin dikkat eksikliği hiperaktivite bozuklugu ile ilişkisi. Uzmanlık Tezi, Pamukkale Üniversitesi Tıp Fakültesi, Denizli.

Aydoğdu, C. (2003). Televizyon ve bilgisayarın ( 18-24 yaş) gençler üzerindeki psikolojik etkileri: Hendek örneği. Yayımlanmamış Yüksek Lisans Tezi, Sakarya Üniversitesi Sosyal Bilimler Enstitüsü, Sakarya.

Balta, Ö.Ç. ve Horzum, M.B. (2008). Web tabanlı öğretim ortamındaki öğrencilerin internet bağımlılı̆ını etkileyen faktörler. Ankara Üniversitesi Eğitim Bilimleri Fakültesi Dergisi, 41, 185-203.

Balcı, Ş. ve Gülnar, B. (2009). Üniversite öğrencileri arasında internet bağımlılığı ve internet bağımlılarının profili. Selçuk iletişim, 6, 1, (5-22).

Banwari, G., Maniar, R., Parmar, C. \& Yadav, P. (2013). Internet addiction and it's correlates among high school students: A preliminary study from Ahmedabad, India. Asian Journal of Psychiatry, 6 (2013), 500-505. 3 Temmuz 2015 tarihinde

http://www.asianjournalofpsychiatry.com/article/S1876-2018(13)00167-6/pdf sayfasından erişilmiştir.

Batıgün, A. D. ve Kılıç, N. (2011). İnternet bağımlılığı ile kişilik özellikleri, sosyal destek, psikolojik belirtiler ve bazı sosyo-demografik değişkenler arasındaki illişkiler. Türk Psikoloji Dergisi, 26 (67), 1-10.

| Kastamonu Eğitim Dergisi, 27(5), 2019| 
Bayraktar, F. (2001). İnternet kullanımının ergen gelişimindeki rolü. Yayımlanmamış Yüksek Lisans Tezi, Ege Üniversitesi Sosyal Bilimler Enstitüsü, İzmir.

Bayraktar, F. (2007). Olumlu ergen gelişiminde ebeveyn/akran ilişkilerinin önemi. Çocuk ve Gençlik Ruh Sağlığı Dergisi, 14(3), 157166.

Bayraktar, F. \& Gün, Z. (2007). Incidence and correlates of internet usage among adolescents in North Cyprus. Cyberpsychology \& Behavior,10, 191-197.

Cao, F. \& Su, L. (2007). Internet addiction among Chinese adolescents: prevalence and psychological features.Child Care Health Development, 33(3), 275-81.

Caplan, S. E. (2002). Problematic internet use and psychosocial well-being: Development of a theory-based cognitive-behavioral measurement instrument. Computers in Human Behavior, 18, 553-575.

Caplan, S. E. (2007). Relations among loneliness, social anxiety, and problematic internet use. Cyber Psycehology and Behavior, 2(10), 234-242.

Cengizhan, C. (2005). Öğrencilerin bilgisayar ve internet kullanımında yeni bir boyut: bağımlılık. VIII. Ulusal PDR Kongresi, Marmara Üniversitesi, İstanbul.

Ceyhan, A. A. (2011). Ergenlerin problemli internet kullanım düzeylerinin yordayıcıları. Çocuk ve Gençlik Ruh Sağ/ığı Dergisi, 18(2), 85-94.

Duman, M. Z. (2008). İnternet kullanımının öğrencilerin sosyal ilişkileri ve okul başarıları üzerindeki etkisi. Toplum ve Demokrasi, 2(3), 93-112.

Esen, E. \& Siyez, D. M. (2011). Ergenlerde internet bağımlılığını yordayan psiko-sosyal değişkenlerin incelenmesi. Türk Psikolojik Danışma Rehberlik Dergisi, 4 (36), 127138.

Esen, E. (2010). Ergenlerde internet bağımlılığını yordayan psiko-sosyal değişkenlerin incelenmesi. Yayımlanmamış Yüksek Lisans Tezi, Dokuz Eylül Üniversitesi Eğitim Bilimleri Enstitüsü, İzmir.

Gökçearslan, Ş. \& Günbatar, M.S. (2012). Ortaöğrenim Öğrencilerinde İnternet Bağımlılığı. Eğitim Teknolojisi Kuram ve Uygulama. Cilt:2 Sayı:2, 10-24

Gönül, A. S. (2002) Patolojik internet kullanımı (internet bağımlılığı / kötüye kullanım.). New Symposium, 40 (3), 105-110.

Günüç, S. (2009). Internet bağımlıık ölçeğinin geliştirilmesi ve bazı demografik değişkenler ile internet bağımlılı̆ı arasındaki ilişkilerin incelenmesi. Yayımlanmamış Yüksek Lisans Tezi, Yüzüncü Yıl Üniversitesi Sosyal Bilimler Enstitüsü, Van.

Gürcan, N. (2010). Ergenlerin problemli internet kullanımları ile uyumları arasindaki ilişkinin incelenmesi. Yayımlanmamış Yüksek Lisans Tezi, Selçuk Üniversitesi Eğitim Bilimleri Enstitüsü, Konya.

Grohol, J.M. (2012). Internet addiction guide. http://psychcentral.com/netaddiction sayfasından erişilmiştir.

Internet World Stats (2015). Internet in europe stats - internet user statistics/population for the 53th european countries and regions. 30 Ekim 2015 tarihinde http://www.internetworldstats.com/stats4.htm sayfasından erişilmiştir.

Internet World Stats (2015). Internet usage statistics - the big picture/world internet users and population stats. 30 Ekim 2015 tarihinde http://www.internetworldstats.com/stats.htm sayfasından erişilmiştir.

Internet World Stats (2016). Internet usage statistics - the big picture/world internet users and population stats. 20 Ağustos 2016 tarihinde http://www.internetworldstats.com/stats.htm sayfasından erişilmiştir.

Internet World Stats (2017). Internet usage statistics - the big picture/world internet users and population stats. 12 Haziran 2018 tarihinde https://www.internetworldstats.com/stats.htm sayfasından erişilmiştir.

Internet World Stats (2019). Internet usage statistics - the big picture/world internet users and population stats. 17 Ağustos 2019 tarihinde https://www.internetworldstats.com/stats4.htm\#europe sayfasından erişilmiştir.

İmpraim, S. (2012). İnternet bağımlılı̆̆ı, facebook kullanımı ve akademik başarı arasındaki ilişkinin incelenmesi. Yayımlanmamış Yüksek Lisans Tezi, Fatih Üniversitesi Sosyal Bilimler Enstitüsü, İstanbul.

İnan, A. (2010). İlkögretim II. Kademe ve Ortaöğretim Öğrencilerinde İnternet Bağımlılığı. Yayımlanmamış Yüksek Lisans Tezi, Atatürk Üniversitesi Sosyal Bilimler Enstitüsü, Erzurum.

Jang, K.S. , Hwang, S.Y. ve Choi, J.Y. (2008). Internet addiction and psychiatric symptoms among Korean adolescents. Journal of School Health, 78, 165-171.

Jöreskog, K.G. \& Sörbom, D. (2004). LISREL 8.7 for Windows [Computer software]. Lincolnwood, IL: Scientific Software International, Inc.

Kang, M., Kim, E. \& Park, s. (2014). Social relationship on problematic internet use among adolescents in South korea: a moderated mediation model of self esteem and self control. Computers in Human Behavior, 38 (2014), 349-397.

Kıran-Esen, B. \& Gündoğdu, M. (2010). The relationship between internet addiction, peer pressure and perceived social support among adolescents. The International Journal of Educational Researchers, 2(1):29-36.

Kozaklı, H. (2006). Üniversite öğrencilerinde yalnızıık ve sosyal destek düzeyleri arasındaki ilişkilerin karşılaştırılması. Yayımlanmamış Yüksek Lisans Tezi, Mersin Üniversitesi Sosyal Bilimler Enstitüsü, Mersin. 
Kuran, E. (2018). Telgraftan Tablete. İstanbul: Destek Yayınları.

Makas, Y. (2008). Lise öğrenimi gören gençlerin internet kullanımnın psikososyal durum ile ilişkisi. Yayımlanmamış Yüksek Lisans Tezi, Beykent Üniversitesi Sosyal Bilimler Enstitüsü, İstanbul.

Mitchell, M.E. , Lebow, J.R. , Uribe, R. , Grathouse, H. \& Shoger, W. (2011). Internet use, happiness, social support and introversion: A more fine grained analysis of person variables and internet activity. Computers in Human Behaviour, 27 (2011), 1857-1861.

Morahan-Martin, J. \& Schumacher, P. (2000). Incidence and correlates of pathological internet use among college students. Computers in Human Behavior, 16, 13-29.

Mossbarger, B. (2008). Is Internet addiction addressed in the classroom? A survey of psychology textbooks. Computers in Human Behavior, 24, 468-474.

Ögel, K. (2014). Internet bağımlıığı, internetin psikolojisini anlamak ve bağımlııkla başa çıkmak. İstanbul: Türkiye İş Bankası.

Ulutaşdemir, N. , Verim, E. , Bakır, E. ve Deniz, E. (2017). Geleceğin sağlık profesyonellerinde internet bağımlılı̆ının yaşam kaliteleri üzerine etkisi. Zeynep Kamil Tıp Bülteni, 42(2).

Pawlak, C. (2002). Correlates of internet use and addiction in adolescents. Dissertation Abstracts International Section A: Humanities \& Social Sciences, 63(5-A), 1727.

Sanders, C., Field, T., Diego, M., \& Kaplan, M. (2000). The relationship of internet use to depression and social isolation among adolescents. Adolescence, 35(138), 237-242.

Schermelleh-Engel, K., Moosbrugger, H., \& Müller, H. (2003). Evaluating the fit of structural equation models: Tests of significance and descriptive goodness-of-fit measures. Methods of psychological research online, 8(2), 23-74.

Suhail, K. \& Bargees, Z. (2006). Effects of excessive internet use on undergraduate students in Pakistan. CyberPsychology \& Behavior, 9; 297-307

Suler, J. (1999). Healthy and pathological internet use. CyberPsychology and Behavior, 2, 385-394.

Tanrıverdi, S. (2012). Ortaöğretim öğrencilerinde internet bağımlılığı ile algılanan sosyal destek arasındaki ilişkinin incelenmesi. Yayımlanmamış Yüksek Lisans Tezi, Yüzüncü Yıl Üniversitesi Eğitim Bilimleri Enstitüsü, Van.

Toraman, M. (2013). İnternet bağımlıı̆̆ı ve sosyal ağ kullanım düzeylerinin ortaöğretim öğrencilerinin akademik başarıları ile ilişkisinin incelenmesi. Yayımlanmamış Yüksek Lisans Tezi, Fırat Üniversitesi Eğitim Bilimleri Enstitüsü, Elazığ.

Tsai, C.C. ve Lin, S.S.J., Tsai, M.J. (2001). Developing an internet attitude scale for high school students. Computers \& Education, $37(1), 41-51$.

TÜík (2013). Hanehalkı bilişim teknolojileri kullanım araştırması. 20 Ağustos 2015 tarihinde http://tuik.gov.tr/PreHaberBultenleri. do?id=13569 sayfasından erişilmiştir.

TÜiK (2014). Hanehalkı bilişim teknolojileri kullanım araştırması. 20 Ağustos 2015 tarihinde http://www.tuik.gov.tr/PreHaberBultenleri.do?id=16198 sayfasından erişilmiştir.

TÜik (2015) Hanehalkı bilişim teknolojileri kullanım araştırması. 27 Ağustos 2015 tarihinde http://www.tuik.gov.tr/PreHaberBultenleri.do?id=18660 sayfasından erişilmiştir.

TÜik (2017) Hanehalkı bilişim teknolojileri kullanım araştırması. 10 Mayıs 2018 tarihinde http://www.tuik.gov.tr/PreTablo.do?alt_ id=1028 sayfasından erişilmiştir.

TÜiK (2018) Hanehalkı bilişim teknolojileri kullanım araştırması. 26 Kasım 2018 tarihinde http://www.tuik.gov.tr/PreHaberBultenleri.do?id=27819 sayfasından erişilmiştir.

Üneri, Ö. Ş. ve Tanıdır, C. (2011) .Bir grup lise öğrencisinde internet bağımlılığı değerlendirmesi: kesitsel bir çalışma. Düşünen Adam Psikiyatri ve Nörolojik Bilimler Dergisi 24, 265- 272

Yalçın, C. (2003). Sosyolojik bir bakış açısıyla internet. Cumhuriyet Üniversitesi Fen-Edebiyat Fakültesi Sosyal Bilimler Dergisi, 27(1), 77-90.

Yang, S. C. \& Tung, C. J. (2007). Comparison of internet addicts and nonaddicts in Taiwanese high school. Computers in Human Behavior, 23: 79-96.

Yıldırım, İ. (1997). Algılanan sosyal destek ölçeğinin geliştirilmesi güvenirliği ve geçerliği. Hacettepe Üniversitesi Eğitim Fakültesi Dergisi, 13, 81-87.

Yıldırım, i. (2004). Algılanan sosyal destek ölçeğinin revizyonu. Eğitim Araştırmaları Dergisi, 17, 221-236.

Young, K. (1998) Internet addiction: The emergence of a new clinical disorder. CyberPsychology \& Behavior, 1, (3), 237-244

Zorbaz, O. (2013). Lise öğrencilerinin problemli internet kullanımının sosyal kaygı ve akran ilişkileri açısından incelenmesi. Yayımlanmamış Yüksek Lisans Tezi, Hacettepe Üniversitesi Sosyal Bilimler Enstitüsü, Ankara. 